\title{
Diphenylamido Precursors to Bisalkoxide Molybdenum Olefin Metathesis Catalysts
}

\author{
Amritanshu Sinha $\ddagger$, Richard R. Schrock $\ddagger$, Peter Müller ${ }^{\ddagger}$, and Amir H. Hoveyda ${ }^{\dagger}$ \\ $\$$ Department of Chemistry 6-331, Massachusetts Institute of Technology, Cambridge, Massachusetts 02139 \\ $\dagger$ Department of Chemistry, Merkert Chemistry Center, Boston College Chestnut Hill, Massachusetts 02467
}

\begin{abstract}
We have found that $\mathrm{Mo}(\mathrm{NAr})\left(\mathrm{CHR}^{\prime}\right)\left(\mathrm{NPh}_{2}\right)_{2}\left(\mathrm{R}^{\prime}=\mathrm{t}-\mathrm{Bu}\right.$ or $\left.\mathrm{CMe}_{2} \mathrm{Ph}\right)$ and $\mathrm{Mo}\left(\mathrm{NAr}^{\prime}\right)\left(\mathrm{CHCMe}_{2} \mathrm{Ph}\right)$ $\left(\mathrm{NPh}_{2}\right)_{2}\left(\mathrm{Ar}=2,6-\mathrm{i}-\mathrm{Pr}_{2} \mathrm{C}_{6} \mathrm{H}_{3} ; \mathrm{Ar}^{\prime}=2,6-\mathrm{Me}_{2} \mathrm{C}_{6} \mathrm{H}_{3}\right)$ can be prepared through addition of two equivalents of $\mathrm{LiNPh}_{2}$ to $\mathrm{Mo}\left(\mathrm{NR}^{\prime \prime}\right)\left(\mathrm{CHR}^{\prime}\right)(\mathrm{OTf})_{2}(\mathrm{dme})$ species $\left(\mathrm{R}^{\prime \prime}=\mathrm{Ar}\right.$ or $\mathrm{Ar}^{\prime} \mathrm{dme}=1,2-$ dimethoxyethane), although yields are low. A high yield route consists of addition of $\mathrm{LiNPh}_{2}$ to bishexafluro-t-butoxide species. An X-ray structure of $\mathrm{Mo}(\mathrm{NAr})\left(\mathrm{CHCMe}{ }_{2} \mathrm{Ph}\right)\left(\mathrm{NPh}_{2}\right)_{2}$ reveals that the two diphenylamido groups are oriented in a manner that allows an 18 electron count to be achieved. The diphenylamido complexes react readily with $\mathrm{t}-\mathrm{BuOH}$ and $\left(\mathrm{CF}_{3}\right)_{2} \mathrm{MeCOH}$, but not readily with the sterically demanding biphenol $\mathrm{H}_{2}$ [Biphen] (Biphen ${ }^{2-}=3,3^{\prime}$-Di-t-butyl-5,5',6,6'tetramethyl-1,1'-Biphenyl-2,2'-diolate). The diphenylamido complexes do react with various 3,3'disubstituted binaphthols to yield binaphtholate catalysts that can be prepared in situ and employed for a simple asymmetric ring-closing metathesis reaction. In several cases conversions and enantioselectivities were comparable to reactions in which isolated catalysts were employed.
\end{abstract}

\section{Introduction}

We have been searching for methods of synthesizing Mo(NR)(CHR')(OR" $)_{2}$ species (or related species that contain enantiomerically pure biphenolate or binaphtholate ligands ${ }^{1}$ ) in situ. The main reason is that an increasing number of applications (e.g., asymmetric olefin

metathesis ${ }^{1}$ ) require an evaluation of many catalysts having different combinations of imido and alkoxide ligands for a given chemical transformation and therefore the synthesis, isolation, and storage of many catalysts. It also would be desirable to synthesize well-defined supported catalysts (e.g., on partially dehydroxylated silica ${ }^{2}$ ). We have reported the synthesis of catalysts in situ in a manner that is essentially the same as that employed to prepare and isolate each catalyst, i.e., addition of the potassium salt of a biphenolate or a binaphtholate to a $\mathrm{Mo}(\mathrm{NR})$ $\left(\mathrm{CHR}^{\prime}\right)(\mathrm{OTf})_{2}(\mathrm{dme})$ species in THF. ${ }^{3}$ However, the most attractive goal would be to prepare a $\mathrm{Mo}(\mathrm{NR})\left(\mathrm{CHR}^{\prime}\right) \mathrm{X}_{2}$ precursor that could be transformed readily into $\mathrm{Mo}(\mathrm{NR})\left(\mathrm{CHR}^{\prime}\right)\left(\mathrm{OR}^{\prime \prime}\right)_{2}$ (or a related biphenolate or binaphtholate species) simply through addition of the monoalcohol or diol to the $\mathrm{Mo}(\mathrm{NR})\left(\mathrm{CHR}^{\prime}\right) \mathrm{X}_{2}$ precursor. This method would require that the HX product of this reaction not interfere to any significant degree with subsequent reactions that involve Mo $(\mathrm{NR})\left(\mathrm{CHR}^{\prime}\right)\left(\mathrm{OR}^{\prime \prime}\right)_{2}$, and also not react with any organic species in the reaction. A wide variety of $\mathrm{Mo}(\mathrm{NR})\left(\mathrm{CHR}^{\prime}\right)\left(\mathrm{OR}^{\prime \prime}\right)_{2}$ catalysts then could be generated in situ and evaluated relatively rapidly. We first focused on species in which $\mathrm{X}=\mathrm{CH}_{2} \mathrm{CMe}_{3}$, but we found that $\mathrm{Mo}(\mathrm{NAr})(\mathrm{CH}-$ $\mathrm{t}-\mathrm{Bu})\left(\mathrm{CH}_{2}-\mathrm{t}-\mathrm{Bu}\right)_{2}$ and related species react with only one equivalent of alcohols to yield complexes of the type $\mathrm{Mo}(\mathrm{NAr})(\mathrm{CH}-\mathrm{t}-\mathrm{Bu})\left(\mathrm{CH}_{2}-\mathrm{t}-\mathrm{Bu}\right)(\mathrm{OR})$, or precursors to them, $\mathrm{Mo}(\mathrm{NAr})$ $\left(\mathrm{CH}_{2} \text {-t-Bu }\right)_{3}(\mathrm{OR})$ spercies, ${ }^{4}$ even on silica surfaces. ${ }^{5}$ Although $\mathrm{Mo}(\mathrm{NAr})(\mathrm{CH}-\mathrm{t}-\mathrm{Bu})\left(\mathrm{CH}_{2}\right.$-t- 
$\mathrm{Bu})(\mathrm{OR})$ and related species are surprisingly active catalysts and are of fundamental interest in their own right, we had to reevaluate our approach to bisalkoxide precursors.

Amido groups have been employed extensively in transition metal chemistry, especially early metal chemistry, and it is well known that they often can be protonated readily. ${ }^{6}$ Some high oxidation state Mo chemistry reported by Cummins is especially noteworthy. He and his group have prepared trisalkoxide complexes of the type $\mathrm{Mo}(\mathrm{X})(\mathrm{OAd})_{3}$ through addition of three equivalents of adamantanol to $\mathrm{Mo}(\mathrm{X})\left[\mathrm{N}(\mathrm{i}-\mathrm{Pr})\left(3,5-\mathrm{C}_{6} \mathrm{H}_{3} \mathrm{Me}_{2}\right)\right]_{3}$ species $\left(\mathrm{X}=\mathrm{CCH}_{2} \mathrm{SiMe}_{3}{ }^{7}\right.$, $\left.\mathrm{N}^{8}, \mathrm{P}^{9}\right)$. Moore has extended this approach in order to prepare alkylidyne catalysts of molybdenum for the metathesis of alkynes. ${ }^{10}$ Therefore we turned to the possibility of preparing bisamido catalyst precursors, $\mathrm{Mo}(\mathrm{NR})\left(\mathrm{CHR}^{\prime}\right)(\text { amido })_{2}$.

The only known $\mathrm{M}(\mathrm{NR})\left(\mathrm{CHR}^{\prime}\right)(\text { amido })_{2}(\mathrm{M}=\mathrm{Mo}$ or $\mathrm{W})$ species is $\mathrm{W}(\mathrm{NAr})(\mathrm{CHEt})\left(\mathrm{NPh}_{2}\right)_{2}$, which was prepared in $73 \%$ yield as golden-orange crystals upon treating $\mathrm{W}(\mathrm{CHEt})(\mathrm{NAr})$ $\left[\mathrm{OCMe}\left(\mathrm{CF}_{3}\right)_{2}\right]_{2}(3 \text {-hexene })_{0.8}$ with 2 equivalents of $\mathrm{LiNPh}_{2} .{ }^{11}$ (W(CHEt)(NAr)[OCMe $\left.\left(\mathrm{CF}_{3}\right)_{2}\right]_{2}$ (3-hexene $)_{0.8}$ is believed to be a mixture of a propylidene complex and a triethylmetallacyclobutane complex.) Complexes that contain chelating (diamido) ligands are known, e.g., molybdenum complexes that contain a N,N'-disubstituted-2,2'-bisamido-1,1'binaphthyl ligand. ${ }^{12}$ Boncella has isolated $\mathrm{M}(\mathrm{NPh})(\mathrm{CH}-\mathrm{t}-\mathrm{Bu})\left[o-\left(\mathrm{Me}_{3} \mathrm{SiN}\right)_{2} \mathrm{C}_{6} \mathrm{H}_{4}\right]\left(\mathrm{PMe}_{3}\right)(\mathrm{M}$ $=\mathrm{Mo}, \mathrm{W})$ species as the products of the reactions between $\mathrm{M}(\mathrm{NPh})\left(\mathrm{CH}_{2}-\mathrm{t}-\mathrm{Bu}\right)_{2}[\mathrm{o}-$ $\left.\left(\mathrm{Me}_{3} \mathrm{SiN}\right)_{2} \mathrm{C}_{6} \mathrm{H}_{4}\right](\mathrm{M}=\mathrm{Mo}, \mathrm{W})$ and 5 equivalents of $\mathrm{PMe}_{3}$, and other chemistry of both Mo and $\mathrm{W}$ compounds that contain the $\left[o-\left(\mathrm{Me}_{3} \mathrm{SiN}\right)_{2} \mathrm{C}_{6} \mathrm{H}_{4}\right]^{2-}$ diamido ligand has been published. 13,14 In view of the existence of $\mathrm{W}(\mathrm{NAr})(\mathrm{CHEt})\left(\mathrm{NPh}_{2}\right)_{2}$ we therefore first sought to prepare $\mathrm{Mo}(\mathrm{NAr})(\mathrm{CH}-\mathrm{t}-\mathrm{Bu})\left(\mathrm{NPh}_{2}\right)_{2}$ and to employ it as a precursor for the in situ synthesis of asymmetric metathesis catalysts. This paper reports the results of these and related studies.

\section{Results}

\section{Synthesis of bisdiphenylamido species}

Addition of a cold suspension of two equivalents of $\mathrm{LiNPh}_{2}$ in THF or toluene to a stirred suspension of $\mathrm{Mo}(\mathrm{NAr})\left(\mathrm{CHR}^{\prime}\right)(\mathrm{OTf})_{2}(\mathrm{dme})\left(\mathrm{R}^{\prime}=\mathrm{t}-\mathrm{Bu}, \mathrm{CMe}_{2} \mathrm{Ph}\right)$ in $\mathrm{THF}$ at -25 to $-30{ }^{\circ} \mathrm{C}$ produced $\mathrm{Mo}(\mathrm{NAr})(\mathrm{CH}-\mathrm{t}-\mathrm{Bu})\left(\mathrm{NPh}_{2}\right)_{2}$ as a red solid, but the isolated yield was only $12 \%$. The yield in the case of $\mathrm{Mo}(\mathrm{NAr})\left(\mathrm{CHCMe}_{2} \mathrm{Ph}\right)\left(\mathrm{NPh}_{2}\right)_{2}$ was $35 \%$. In both cases much manipulation was required to isolate a solid product. Alkylidene proton resonances for $\mathrm{Mo}(\mathrm{NAr})(\mathrm{CH}-\mathrm{t}-\mathrm{Bu})$ $\left(\mathrm{NPh}_{2}\right)_{2}$ and $\mathrm{Mo}(\mathrm{NAr})\left(\mathrm{CHCMe}_{2} \mathrm{Ph}\right)\left(\mathrm{NPh}_{2}\right)_{2}$ in benzene- $d_{6}$ are found at $10.96 \mathrm{ppm}$ and 11.18 ppm, respectively, and alkylidene carbon resonances were found at 294.8 and $292.6 \mathrm{ppm}$, respectively. The $\mathrm{J}_{\mathrm{CH}}$ values $(117$ and $119 \mathrm{~Hz}$, respectively) are consistent with a syn orientation of the alkylidene. ${ }^{15,16}$ In the case of $\mathrm{Mo}(\mathrm{NAr})(\mathrm{CHCMe} 2 \mathrm{Ph})\left(\mathrm{NPh}_{2}\right)_{2}$, a second minor alkylidene proton resonance is observed at $11.78 \mathrm{ppm}(\sim 5 \%$ of the total). We ascribe this resonance to the anti isomer, although we have not proven that to be the case through a determination of the value for $\mathrm{J}_{\mathrm{CH}}$.

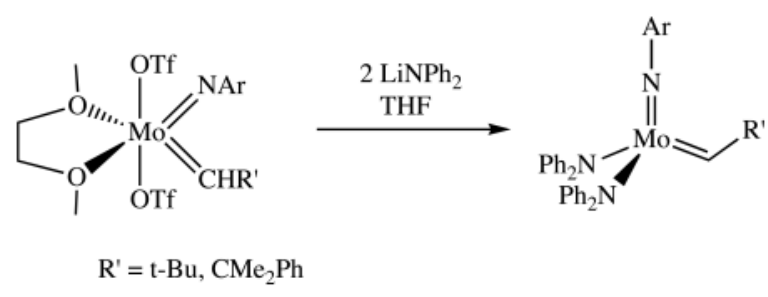

(1).

Single crystals of $\mathrm{Mo}(\mathrm{NAr})\left(\mathrm{CHCMe}_{2} \mathrm{Ph}\right)\left(\mathrm{NPh}_{2}\right)_{2}$ suitable for X-ray crystallographic studies were obtained by layering a concentrated solution of the complex in dichloromethane with a 
minimum amount of pentane and storing the sample at $-30{ }^{\circ} \mathrm{C}$. In the solid state $\mathrm{Mo}(\mathrm{NAr})$ $\left(\mathrm{CHCMe}_{2} \mathrm{Ph}\right)\left(\mathrm{NPh}_{2}\right)_{2}$ has a pseudo tetrahedral geometry about the metal with the alkylidene ligand in the syn orientation, as expected (Figure 1). The Mo-C(37) double bond distance (1.877 (3) $\AA$ ) and the Mo- $\mathrm{C}(37)-\mathrm{C}(38)$ bond angle $\left(146.2(3)^{\circ}\right)$ are typical of those found in a syn complex of this general type. ${ }^{15,16}$ The Mo- $\mathrm{N}_{\text {amide }}$ bond lengths (2.009(3) $\AA$ and 2.007(3) $\AA$ ) are similar to those found in a complex that contains a chelating diamido ligand, $\mathrm{Mo}(\mathrm{NAr})$ $\left(\mathrm{CHCMe}_{2} \mathrm{Ph}\right)\left[\mathrm{BINA}(\mathrm{N}-\mathrm{i}-\mathrm{Pr})_{2}\right]\left(\mathrm{Mo}-\mathrm{N}_{\text {amide }}=1.993 \AA\right.$; $\left[\mathrm{BINA}(\mathrm{N}-\mathrm{i}-\mathrm{Pr})_{2}\right]^{2-}=\mathrm{N}, \mathrm{N}^{\prime}-$ diisopropyl-2,2'-bisamido-1,1'-binaphthyl). ${ }^{12}$ The amido nitrogen atoms are essentially planar, as expected, and the two amido planes are virtually perpendicular to one another, as in $\mathrm{Mo}(\mathrm{NAr})\left(\mathrm{CHCMe}_{2} \mathrm{Ph}\right)\left[\mathrm{BINA}(\mathrm{N}-\mathrm{i}-\mathrm{Pr})_{2}\right]$. Therefore the lone pairs from both amido nitrogens can be donated to the metal and the total electron count at the metal can be said to be 18 .

The main problem with the route shown in equation 1 appears to be deprotonation of the alkylidene to yield a mixture of alkylidyne and other species, and diphenylamine. This type of side reaction has been documented in some cases, ${ }^{17}$ but not for reactions that involve amides. Since diphenylamine is extremely difficult to separate from the desired products, we believe that it is the presence of diphenylamine, rather than an inherently low yield, that limits how much pure product can be isolated, a statement that is supported by NMR analysis of crude reaction mixtures. In view of the reported synthesis of W(NAr) $(\mathrm{CHEt})\left(\mathrm{NPh}_{2}\right)_{2}{ }^{11}$ (vide supra) we therefore explored bishexafluoro-t-butoxides as starting materials.

$\mathrm{Mo}(\mathrm{NAr})\left(\mathrm{CHCMe}_{2} \mathrm{Ph}\right)\left[\mathrm{OCMe}\left(\mathrm{CF}_{3}\right)_{2}\right]_{2}$ can be obtained as yellow crystals in $\sim 85 \%$ yield in the reaction between $\mathrm{Mo}(\mathrm{NAr})\left(\mathrm{CHCMe}_{2} \mathrm{Ph}\right)(\mathrm{OTf})_{2}(\mathrm{dme})$ and 2 equivalents of LiOCMe $\left(\mathrm{CF}_{3}\right)_{2}$ in diethyl ether. ${ }^{18}$ (Hexafluoro-t-butoxide is a relatively weak base that does not deprotonate the alkylidene.) Treating a prechilled solution $\left(-30^{\circ} \mathrm{C}\right)$ of $\mathrm{Mo}(\mathrm{NAr})\left(\mathrm{CHCMe} \mathrm{CH}_{2} \mathrm{Ph}\right)$ $\left[\mathrm{OCMe}\left(\mathrm{CF}_{3}\right)_{2}\right]_{2}$ in diethyl ether with two equivalents of $\mathrm{LiNPh}_{2}\left(0.5 \mathrm{Et}_{2} \mathrm{O}\right)$ afforded $\mathrm{Mo}(\mathrm{NAr})$ $\left(\mathrm{CHCMe}_{2} \mathrm{Ph}\right)\left(\mathrm{NPh}_{2}\right)_{2}$ as bright orange crystals in $78 \%$ isolated yield (equation 2). $\mathrm{Mo}\left(\mathrm{NAr}^{\prime}\right)$ $\left(\mathrm{CHCMe}_{2} \mathrm{Ph}\right)\left(\mathrm{NPh}_{2}\right)_{2}$ can be prepared similarly as red-orange crystals in $91 \%$ yield starting from
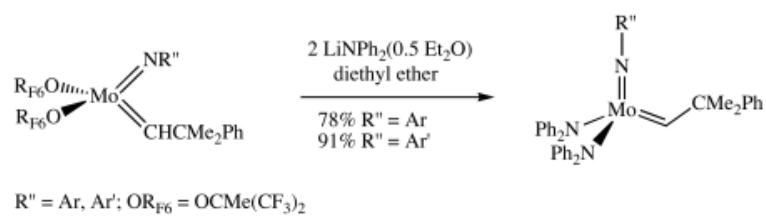

(2).

$\mathrm{Mo}\left(\mathrm{NAr}^{\prime}\right)\left(\mathrm{CHCMe}_{2} \mathrm{Ph}\right)\left[\mathrm{OCMe}\left(\mathrm{CF}_{3}\right)_{2}\right]_{2}$. The complexes prepared in this manner are identical to the samples obtained directly from the bistriflate species. In spite of the extra step (synthesis of hexafluoro-t-butoxides), this is the preferred method of producing pure product in high yield relatively quickly. It is known that the acidity of an alkylidene proton is reduced dramatically in alkoxide (even hexafluoro-t-butoxide) complexes compared to what it is in (e.g.) a triflate or a chloride complex, ${ }^{15}$ so deprotonation of the alkylidene is no longer problematic relative to substitution of the alkoxide.

\section{Synthesis of $\mathrm{Mo}\left[\mathrm{N}\left(\mathrm{R}^{1}\right)\left(3,5-\mathrm{C}_{6} \mathrm{H}_{3} \mathrm{Me}_{2}\right)\right]_{2}$ complexes}

$\mathrm{Mo}(\mathrm{NAr})(\mathrm{CH}-\mathrm{t}-\mathrm{Bu})\left[\mathrm{N}\left(\mathrm{R}^{1}\right)\left(3,5-\mathrm{C}_{6} \mathrm{H}_{3} \mathrm{Me}_{2}\right)\right]_{2}\left(\mathrm{R}^{1}=\mathrm{t}-\mathrm{Bu}, \mathrm{i}-\mathrm{Pr}\right)$ can be synthesized by treating a pre-chilled solution $\left(-30^{\circ} \mathrm{C}\right)$ of $\mathrm{Mo}(\mathrm{NAr})(\mathrm{CH}-\mathrm{t}-\mathrm{Bu})(\mathrm{OTf})_{2}(\mathrm{dme})$ in diethyl ether or toluene with two equivalents of the corresponding $\operatorname{LiN}\left(\mathrm{R}^{1}\right)\left(3,5-\mathrm{C}_{6} \mathrm{H}_{3} \mathrm{Me}_{2}\right)$ (ether) salt. We believe that the yields again are compromised as a consequence of deprotonation of alkylidenes and consequent contamination of the product with the relatively high boiling parent amine. For example, $\mathrm{Mo}(\mathrm{NAr})(\mathrm{CH}-\mathrm{t}-\mathrm{Bu})\left[\mathrm{N}(\mathrm{t}-\mathrm{Bu})\left(3,5-\mathrm{C}_{6} \mathrm{H}_{3} \mathrm{Me}_{2}\right)\right]_{2}$ can be prepared and isolated in pure form as an orange-red crystalline solid in $34 \%$ yield. Proton and carbon NMR data (Table 3) are those expected for syn isomers. No alkylidene resonance for the anti isomer of Mo(NAr) 
$(\mathrm{CH}-\mathrm{t}-\mathrm{Bu})\left[\mathrm{N}(\mathrm{t}-\mathrm{Bu})\left(3,5-\mathrm{C}_{6} \mathrm{H}_{3} \mathrm{Me}_{2}\right)\right]_{2}$ could be found at $22{ }^{\circ} \mathrm{C}$. The $3,5-\mathrm{Me}_{2} \mathrm{C}_{6} \mathrm{H}_{3}$ ring was found to be freely rotating on the NMR timescale. On the other hand, solid $\mathrm{Mo}(\mathrm{NAr})(\mathrm{CH}-\mathrm{t}-$ $\mathrm{Bu})\left[\mathrm{N}(\mathrm{i}-\mathrm{Pr})\left(3,5-\mathrm{C}_{6} \mathrm{H}_{3} \mathrm{Me}_{2}\right)\right]_{2}$ could not be isolated free of $\mathrm{HN}(\mathrm{i}-\mathrm{Pr})\left(3,5-\mathrm{C}_{6} \mathrm{H}_{3} \mathrm{Me}_{2}\right)$ in spite of repeated attempts at triturating the oily material with cold pentane or lyophilizing it in benzene. No improvement in the yield and purity of the desired product was observed when the different solvents (toluene, THF) and/or lower temperatures $\left(-78^{\circ} \mathrm{C}\right)$ were employed.

Attempted syntheses of bisdimethylamido complexes from either Mo(NAr) or Mo(NAr') triflates failed. Complex oily mixtures were obtained from which the pure products could not be isolated. Bright orange $\mathrm{Mo}(\mathrm{NAr})\left(\mathrm{CHCMe}_{2} \mathrm{Ph}\right)\left(\mathrm{NMe}_{2}\right)_{2}$ could be obtained in a reaction between 2 equivalents of $\mathrm{LiNMe}_{2}$ and $\mathrm{Mo}(\mathrm{NAr})\left(\mathrm{CHCMe}_{2} \mathrm{Ph}\right)\left[\mathrm{OCMe}\left(\mathrm{CF}_{3}\right)_{2}\right]_{2}$, but only in $16 \%$ yield $\left(\delta \mathrm{H}_{\alpha}=10.69 \mathrm{ppm}, \delta \mathrm{C}_{\alpha}=270.1 \mathrm{ppm}\right)$. Since this synthesis is not viable in the long run this compound was not fully characterized.

\section{Reactions of $\mathrm{Mo}\left(\mathrm{NR}^{\prime \prime}\right)\left(\mathrm{CHR}^{\prime}\right)\left(\mathrm{NR}_{\mathbf{2}}\right)_{2}$ complexes}

None of the bisamido complexes reacted readily with simple olefins like ethylene and diallylether, or with benzaldehyde (e.g., several equivalents at room temperature over a period of $10 \mathrm{~h}$ ), behavior which is similar to that found for $\left[\mathrm{BINA}(\mathrm{NR})_{2}\right]^{2-}$ complexes. ${ }^{12}$ Although steric factors are significant, the primary reason we believe to be an 18 electron count at the metal center (vide infra).

Both $\mathrm{Mo}(\mathrm{NAr})(\mathrm{CH}-\mathrm{t}-\mathrm{Bu})\left(\mathrm{NPh}_{2}\right)_{2}$ and $\mathrm{Mo}\left(\mathrm{NAr}^{\prime}\right)\left(\mathrm{CHCMe}_{2} \mathrm{Ph}\right)\left(\mathrm{NPh}_{2}\right)_{2}$ react readily with t$\mathrm{BuOH}$ and $\left(\mathrm{CF}_{3}\right)_{2} \mathrm{MeCOH}$. Upon addition of the alcohol to $30 \mathrm{mM}$ benzene solutions of the bisamide complexes, the bisalkoxide species, $\mathrm{Mo}(\mathrm{NAr})(\mathrm{CH}-\mathrm{t}-\mathrm{Bu})(\mathrm{OR})_{2}$ and $\mathrm{Mo}\left(\mathrm{NAr}{ }^{\prime}\right)$ $\left(\mathrm{CHCMe}_{2} \mathrm{Ph}\right)(\mathrm{OR})_{2}\left(\mathrm{OR}=\mathrm{O}-\mathrm{t}-\mathrm{Bu}, \mathrm{OCMe}\left(\mathrm{CF}_{3}\right)_{2}\right)$, are obtained within 10 minutes

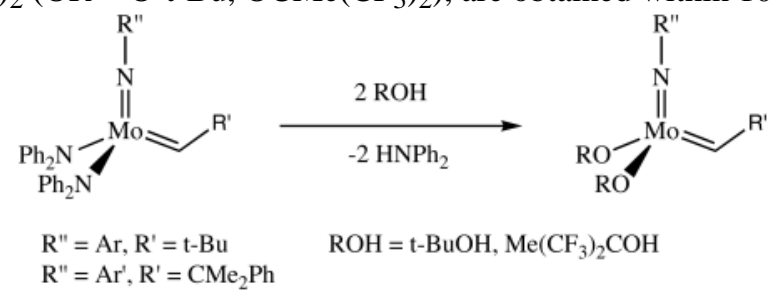

(3).

along with the expected amount of the free amine $\mathrm{Ph}_{2} \mathrm{NH}$ (equation 3). There was no indication that diphenylamine bound to the metal to give an adduct in either case, i.e., the chemical shift of the alkylidene proton is identical to that published for the base-free compounds. There is no evidence of any irreversible protonation of either the imido or the alkylidene ligand.

$\mathrm{Mo}(\mathrm{NAr})\left(\mathrm{CHCMe}_{2} \mathrm{Ph}\right)\left(\mathrm{NPh}_{2}\right)_{2}$ and $\mathrm{Mo}\left(\mathrm{NAr}^{\prime}\right)\left(\mathrm{CHCMe}_{2} \mathrm{Ph}\right)\left(\mathrm{NPh}_{2}\right)_{2}\left(27 \mathrm{mM}\right.$ in benzene- $\left.d_{6}\right)$ also react with one equivalent of $\mathrm{H}_{2}\left[R\right.$-Benz $z_{2}$ Bitet $]$ to give the known Benz ${ }_{2}$ Bitet complexes (equation 4 ). The two reactions proceed $\sim 90 \%$ to completion in $15 \mathrm{~h}$ at room temperature, with

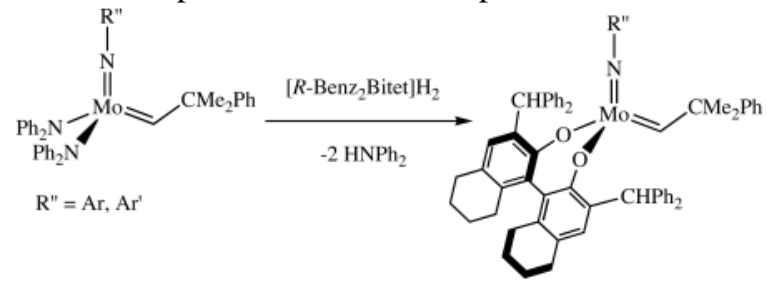

(4).

the reaction involving $\mathrm{Mo}\left(\mathrm{NAr}^{\prime}\right)\left(\mathrm{CHCMe}_{2} \mathrm{Ph}\right)\left(\mathrm{NPh}_{2}\right)_{2}$ proceeding about twice as fast as that involving $\mathrm{Mo}(\mathrm{NAr})\left(\mathrm{CHCMe}_{2} \mathrm{Ph}\right)\left(\mathrm{NPh}_{2}\right)_{2}$ and the conversion being slightly higher, 
presumably as a consequence of the lower steric demands of the 2,6-dimethylphenylimido ligand.

Reactions between $\mathrm{Mo}\left(\mathrm{NR}^{\prime \prime}\right)\left(\mathrm{CHCMe}_{2} \mathrm{Ph}\right)\left(\mathrm{NPh}_{2}\right)_{2}\left(\mathrm{NR}^{\prime \prime}=\mathrm{NAr}, \mathrm{NAr}{ }^{\prime}\right)$ and the sterically demanding biphenol $\mathrm{H}_{2}$ [Biphen] (Biphen ${ }^{2-}=3,3^{\prime}$-Di-t-butyl-5,5',6,6'-tetramethyl-1,1'Biphenyl-2,2'-diolate) were slow and incomplete and in some cases produced byproducts. For example, no reaction was observed when $\mathrm{H}_{2}$ [Biphen] was added to a benzene- $d_{6}(0.1 \mathrm{M})$ solution of $\mathrm{Mo}(\mathrm{NAr})\left(\mathrm{CHCMe}_{2} \mathrm{Ph}\right)\left(\mathrm{NPh}_{2}\right)_{2}$ over a period of 2 days at room temperature. Heating the solution at $50{ }^{\circ} \mathrm{C}$ for 1 day shows $44 \%$ conversion to the desired Mo(NAr) $\left(\mathrm{CHCMe}_{2} \mathrm{Ph}\right)[\mathrm{Biphen}]$ species but also four new alkylidene resonances appeared in the 11.40-11.80 ppm region (a total $20 \%$ of the mixture). The nature of the complex or complexes responsible for the new alkylidene resonances is (are) not known. When Mo(NAr) $\left(\mathrm{CHCMe}_{2} \mathrm{Ph}\right)\left(\mathrm{NPh}_{2}\right)_{2}$ was added to a benzene solution of $\mathrm{H}_{2}$ [Biphen], the extra alkylidene peaks amount to less than $8 \%$ of the reaction mixture. However, complete conversion again was not observed. The reaction between $\mathrm{H}_{2}$ [Biphen] and $\mathrm{Mo}(\mathrm{NAr})\left(\mathrm{CHCMe} \mathrm{e}_{2} \mathrm{Ph}\right)\left(\mathrm{NPh}_{2}\right)_{2}$ was also slow, with only $64 \%$ conversion to $\mathrm{Mo}\left(\mathrm{NAr}^{\prime}\right)\left(\mathrm{CHCMe}_{2} \mathrm{Ph}\right)[\mathrm{Biphen}]$ observed in 7 days at $50{ }^{\circ} \mathrm{C}$ at concentrations of $\sim 0.1 \mathrm{M}$.

The binaphthols $\mathrm{H}_{2}\left[R\right.$-TRIP $\left.{ }_{2} \mathrm{BINO}\right],{ }^{19} \mathrm{H}_{2}\left[R\right.$ - $\left.\mathrm{Ph}_{2} \mathrm{BINO}\right],{ }^{20} \mathrm{H}_{2}\left[\right.$ rac-Mes $\left.{ }_{2} \mathrm{BINO}\right],{ }^{20}$ and $\mathrm{H}_{2}\left[R-\mathrm{TMS}_{2} \mathrm{BINO}\right],{ }^{21}$ react more readily with $\mathrm{Mo}\left(\mathrm{NR}^{\prime \prime}\right)\left(\mathrm{CHCMe}_{2} \mathrm{Ph}\right)\left(\mathrm{NPh}_{2}\right)_{2}\left(\mathrm{NR}^{\prime \prime}=\mathrm{NAr}\right.$, NAr') species than does $\mathrm{H}_{2}$ [Biphen] (Table 4), but still not immediately. The reactions shown in Table 4 were carried out by adding the bisdiphenylamido complex to the diol in 2 drops of benzene- $d_{6}(0.3 \mathrm{M})$. After heating the reaction mixtures for the stipulated time, more solvent was added and the $\%$ conversion and $\%$ product were determined by ${ }^{1} \mathrm{H}$ NMR spectroscopy versus an internal standard. Good to excellent conversions were found for virtually all the reactions, although the product mixture in some cases was found to contain small amounts (5-10\%) of unidentified new alkylidenes along with the desired diolate product. The impurities amounted to $\sim 25 \%$ when the diol employed was $\mathrm{H}_{2}\left[R-\mathrm{TMS}_{2} \mathrm{BINO}\right]$, the dianion of which has not been studied extensively in the context of $\mathrm{Mo}\left(\mathrm{NR}^{\prime \prime}\right)\left(\mathrm{CHCMe}_{2} \mathrm{Ph}\right)($ diolate*) chemistry.

Reactions between alcohols and $\mathrm{Mo}(\mathrm{NAr})\left(\mathrm{CHR}^{\prime}\right)\left[\mathrm{N}\left(\mathrm{R}^{1}\right)\left(3,5-\mathrm{C}_{6} \mathrm{H}_{3} \mathrm{Me}_{2}\right)\right]_{2}$ complexes proceeded only very slowly (according to NMR studies) or not at all compared to similar reactions with $\mathrm{Mo}(\mathrm{NAr})\left(\mathrm{CHR}^{\prime}\right)\left(\mathrm{NPh}_{2}\right)_{2}$ species, probably largely for steric reasons. $\mathrm{Mo}(\mathrm{NAr})$ $(\mathrm{CH}-\mathrm{t}-\mathrm{Bu})\left[\mathrm{N}(\mathrm{t}-\mathrm{Bu})\left(3,5-\mathrm{C}_{6} \mathrm{H}_{3} \mathrm{Me}_{2}\right)\right]_{2}$ reacted at room temperature with $\left(\mathrm{CF}_{3}\right)_{2} \mathrm{MeCOH}$ in benzene- $d_{6}(28 \mathrm{mM})$ to give the bisalkoxide within 10 minutes. However, the analogous reaction proceeded very slowly $(\sim 12-15 \mathrm{~h})$ when t-BuOH was employed. Reactions involving $\mathrm{Mo}(\mathrm{NAr})(\mathrm{CH}-\mathrm{t}-\mathrm{Bu})\left[\mathrm{N}(\mathrm{i}-\mathrm{Pr})\left(3,5-\mathrm{C}_{6} \mathrm{H}_{3} \mathrm{Me}_{2}\right)\right]_{2}$ with both $\left(\mathrm{CF}_{3}\right)_{2} \mathrm{MeCOH}$ and $\mathrm{t}-\mathrm{BuOH}$ were complete in 10 minutes under conditions noted above. All $\mathrm{Mo}(\mathrm{NAr})\left(\mathrm{CHR}^{\prime}\right)\left[\mathrm{N}\left(\mathrm{R}^{1}\right)(3,5-\right.$ $\left.\left.\mathrm{C}_{6} \mathrm{H}_{3} \mathrm{Me}_{2}\right)\right]_{2}$ complexes showed virtually a complete lack of reactivity toward the enantiomerically pure diols shown in Table 4.

Conversions and enantioselectivities in a simple asymmetric ring-closing metathesis reaction (equation 5) are also listed in Table 4. Conversions of the substrate range from 56\% to 97\% with the highest ee being $97 \%$. For the first ${ }^{22}$ and third ${ }^{20}$ entries the ring-closing
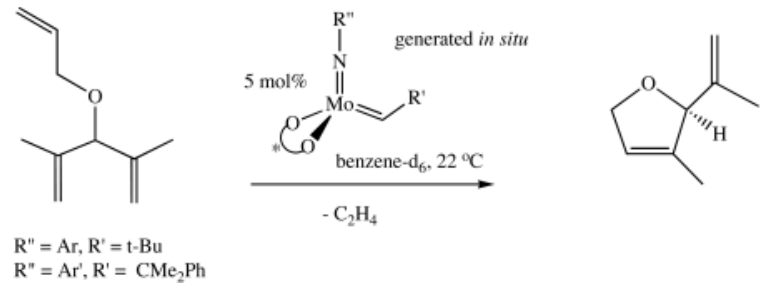

(5).

Organometallics. Author manuscript; available in PMC 2008 November 21. 
also has been carried out with isolated catalyst. The results for the in situ generated catalyst and for the isolated catalyst are comparable. In particular the \%ee's are essentially the same. The in situ catalyst appears to be somewhat slower (first and fourth entries) versus the isolated catalysts, although detailed studies have not been carried out. It should be noted that the first three in situ catalysts that contain a 2,6-dimethylphenyl imido ligand are slightly superior in terms of \%ee than catalysts that contain the 2,6-diisopropylphenyl imido ligand; the 2,6diisopropylphenyl imido derivatives were the only isolated catalysts that were examined.

\section{Conclusions}

We have demonstrated that bisamido complexes can be prepared starting from bistriflate complexes, although yields are low and the products are difficult to isolate. In some cases yields can be improved through the use of $\mathrm{Mo}\left(\mathrm{NR}^{\prime \prime}\right)\left(\mathrm{CHR}^{\prime}\right)\left[\mathrm{OCMe}\left(\mathrm{CF}_{3}\right)_{2}\right]_{2}$ complexes as starting materials. Reactions in which bisdiphenylamido complexes are prepared from hexafluoro-tbutoxide species are high yielding and clean, and for this reason are preferred over reactions that start with bistriflates. On the basis of preliminary studies, NAr and NAr' complexes containing $\mathrm{NPh}_{2}$ ligands react with a variety of enantiomerically pure binaphthols to give the desired chiral catalysts in situ, the exception being $\mathrm{H}_{2}$ [Biphen], which is the most sterically demanding. In these reactions diphenylamine apparently does not bind to the metal, nor does it hinder asymmetric reactions (to the degree that we have explored for one substrate) in terms of either substrate conversion or \%ee. Therefore this approach to in situ catalyst generation and use is an attractive one, especially if a nitrogen-based anionic ligand can be found that produces a catalyst precursor in high yield and if that catalyst precursor were to react with even the most sterically demanding biphenols or binaphthols. In this manner we hope to be able to reduce the problem of catalyst evaluation to the synthesis and storage of a few $\mathrm{Mo}(\mathrm{NR} ")(\mathrm{CHR}$ ') $\mathrm{X}_{2}$ precursors.

\section{Experimental Section}

\section{General}

All operations were performed under a nitrogen atmosphere in the absence of oxygen and moisture in a Vacuum Atmospheres glovebox or using standard Schlenk procedures. All glassware, including NMR tubes, were flame- and/or oven-dried prior to use. Ether, pentane, toluene, and benzene were degassed with dinitrogen and passed through activated alumina columns. Dimethoxyethane was distilled from a dark purple solution of sodium benzophenone ketyl and degassed three time by freeze-pump-thaw techniques. Dichloromethane was distilled from $\mathrm{CaH}_{2}$ under $\mathrm{N}_{2}$. All dried and deoxygenated solvents were stored over $4 \AA$ molecular sieves in a nitrogen-filled glovebox. ${ }^{1} \mathrm{H},{ }^{13} \mathrm{C}$, and ${ }^{19} \mathrm{~F}$ NMR spectra were acquired at room temperature (unless otherwise noted) using Varian Mercury $\left({ }^{1} \mathrm{H} 300 \mathrm{MHz},{ }^{13} \mathrm{C} 75 \mathrm{MHz},{ }^{19} \mathrm{~F}\right.$ $282 \mathrm{MHz}$ ) or Varian Inova $\left({ }^{1} \mathrm{H} 500 \mathrm{MHz},{ }^{13} \mathrm{C} 125 \mathrm{MHz}\right)$ spectrometers and referenced to the residual protio solvent resonances or external $\mathrm{C}_{6} \mathrm{~F}_{6}(-163.0 \mathrm{ppm})$. Elemental Analyses were performed by H. Kolbe Mikroanalytisches Laboratorium, Mülheim an der Ruhr, Germany. Mo $\left(\mathrm{NR}^{\prime \prime}\right)\left(\mathrm{CHR}^{\prime}\right)(\mathrm{OTf})_{2}(\mathrm{dme})$ complexes, $\mathrm{LiN}(\mathrm{i}-\mathrm{Pr})\left(3,5-\mathrm{C}_{6} \mathrm{H}_{3} \mathrm{Me}_{2}\right)$, and $\mathrm{LiN}(\mathrm{t}-\mathrm{Bu})(3,5-$ $\mathrm{C}_{6} \mathrm{H}_{3} \mathrm{Me}_{2}$ ) were prepared as described in the literature. ${ }^{18,23,24,25} \mathrm{LiNPh}_{2}$ was prepared by reacting $\mathrm{HNPh}_{2}$ with $\mathrm{n}-\mathrm{BuLi}$ (1.6 M in hexane) in toluene. $\mathrm{LiNPh}_{2}$ ( 0.5 ether) was obtained by crystallizing $\mathrm{LiNPh}_{2}$ from diethyl ether. $\mathrm{LiNMe}_{2}$ was prepared by reacting $\mathrm{HNMe}_{2}$ with $\mathrm{n}$ $\mathrm{BuLi}(1.6 \mathrm{M}$ in hexane) in toluene. All other chemicals were procured from commercial sources and used as received.

\section{Mo(NAr)(CH-t-Bu)(NPh $)_{2}$}

A solution of $\mathrm{Mo}(\mathrm{NAr})(\mathrm{CH}-\mathrm{t}-\mathrm{Bu})(\mathrm{OTf})_{2}(\mathrm{dme})(6.00 \mathrm{~g}, 8.22 \mathrm{mmol})$ in $80 \mathrm{~mL}$ THF at $-30{ }^{\circ} \mathrm{C}$ was treated with a pre-chilled solution of $\mathrm{LiNPh}_{2}(2.88 \mathrm{~g}, 16.44 \mathrm{mmol})$ in $20 \mathrm{~mL}$ THF. The 
color changed from yellow to red immediately. The reaction mixture was stirred for $1 \mathrm{~h}$ and allowed to warm to room temperature. The volatiles were removed in vacuo and the residue was extracted with pentane. The extracts were filtered through Celite and the solvents again were removed in vacuo to give an oil that was triturated with minimal pentane. Filtration yielded an orange-red powder in $12 \%$ yield $(669 \mathrm{mg})$. The remaining pentane-soluble red oil was found to consist mostly of the desired complex according to proton NMR: ${ }^{1} \mathrm{H}$ NMR $\left(\mathrm{C}_{6} \mathrm{D}_{6}\right) \delta 10.96\left(\mathrm{~s}, 1, \mathrm{CHCMe}{ }_{3}, J_{\mathrm{CH}}=117 \mathrm{~Hz}\right.$ ), 7.12 -6.83 (overlapping peaks, 23, $\mathrm{ArH}$, $\mathrm{NPh}$ ), 3.90 (sept, 2, $\mathrm{CHMe}_{2}$ ), 1.81 (d, 12, CHMe $), 0.98$ (s, 9, $\left.\mathrm{CHCMe}_{3}\right) ;{ }^{13} \mathrm{C} \mathrm{NMR}\left(\mathrm{C}_{6} \mathrm{D}_{6}\right)$ $\delta$ 294.8. Anal. Calcd for $\mathrm{C}_{41} \mathrm{H}_{47} \mathrm{MoN}_{3}$ : C, 72.66; H, 6.99; N, 6.20. Found: C, 72.52; H, 7.08; $\mathrm{N}, 6.11$.

\section{$\mathrm{Mo}(\mathrm{NAr})\left(\mathrm{CHCMe}_{2} \mathrm{Ph}\right)\left(\mathrm{NPh}_{2}\right)_{2}$}

Method A-Mo(NAr) $\left(\mathrm{CHCMe}_{2} \mathrm{Ph}\right)(\mathrm{OTf})_{2}(\mathrm{dme})(500 \mathrm{mg}, 0.63 \mathrm{mmol})$ was dissolve in $8 \mathrm{~mL}$ of THF and the solution was cooled to $-30^{\circ} \mathrm{C}$. A pre-chilled solution of $\mathrm{LiNPh}_{2}(221 \mathrm{mg}, 1.26$ $\mathrm{mmol}$ ) in $2 \mathrm{~mL}$ THF was added to the above solution in a drop-wise fashion to immediately afford a red solution. After 1 hour the volatiles were removed in vacuo to give a red foam which was extracted with pentane. The extract was filtered through Celite and the filtrate was concentrated to dryness to yield a red oil. The oil was triturated with cold pentane several times to give $163 \mathrm{mg}$ of an orange-red powder (35\% yield).

Method B-A yellow solution of $\mathrm{Mo}(\mathrm{NAr})\left(\mathrm{CHCMe}_{2} \mathrm{Ph}\right)\left[\mathrm{OCMe}\left(\mathrm{CF}_{3}\right)_{2}\right]_{2}(505 \mathrm{mg}, 0.66$ $\mathrm{mmol}$ ) in $50 \mathrm{~mL}$ ether was cooled to $-30{ }^{\circ} \mathrm{C}$. Gradual addition of 2 equivalents of $\mathrm{LiNPh}_{2}\left(\mathrm{Et}_{2} \mathrm{O}\right)_{0.5}(280 \mathrm{mg}, 1.32 \mathrm{mmol})$ to the above reaction resulted in a change in color from yellow to orange to red as the reaction mixture was allowed to warm to room temperature. The reaction mixture was stirred for $1 \mathrm{~h}$. The solvents were partially removed and the concentrated solution layered with $5 \mathrm{~mL}$ pentane; bright orange product crystallized out. The orange crystals were washed with $5 \mathrm{~mL}$ of cold pentane $\left(-30^{\circ} \mathrm{C}\right)$ to afford the desired complex in $78 \%$ yield $(380 \mathrm{mg})$ in two crops: ${ }^{1} \mathrm{H}$ NMR $\left(\mathrm{C}_{6} \mathrm{D}_{6}\right) \delta 11.78$ (s, 0.04, anti $\left.\mathrm{CHCMe}_{2} \mathrm{Ph}\right), 11.18$ (s, 1 , syn $\mathrm{CHCMe}_{2} \mathrm{Ph}, J_{\mathrm{CH}}=119 \mathrm{~Hz}$ ), 7.10-6.79 (overlapping peaks, 28, $\mathrm{ArH}, \mathrm{NPh}$ ), 3.86 (sept, 2, $\left.\mathrm{CHMe}_{2}\right), 1.45$ (s, 6, CHCMe $2 \mathrm{Ph}$ ), 1.61 (d, 12, CHMe $) ;{ }^{13} \mathrm{C} \mathrm{NMR}\left(\mathrm{C}_{6} \mathrm{D}_{6}\right) \delta 292.6,155.5$, 154.1, 148.5, 146.3, 129.9, 128.9, 127.8, 126.5, 126.4, 124.6, 123.9, 123.6, 55.7, 31.0, 28.6, 24.7. Anal. Calcd for $\mathrm{C}_{46} \mathrm{H}_{49} \mathrm{MoN}_{3}$ : C, 74.68; H, 6.68; N, 5.68. Found: C, 74.57; H, 6.62; N, 5.69 .

\section{$\mathrm{Mo}\left(\mathrm{NAr}^{\prime}\right)\left(\mathrm{CHCMe}_{2} \mathrm{Ph}\right)\left(\mathrm{NPh}_{2}\right)_{2}$}

$\mathrm{Mo}(\mathrm{NAr})\left(\mathrm{CHCMe}_{2} \mathrm{Ph}\right)\left[\mathrm{OCMe}\left(\mathrm{CF}_{3}\right)_{2}\right]_{2}(539 \mathrm{mg}, 0.76 \mathrm{mmol})$ in $55 \mathrm{~mL}$ ether was chilled to $-30{ }^{\circ} \mathrm{C}$. Gradual addition of 2 equivalents of $\mathrm{LiNPh}_{2}\left(\mathrm{Et}_{2} \mathrm{O}\right)_{0.5}(322 \mathrm{mg}, 1.52 \mathrm{mmol})$ to the above reaction resulted in a change in color from yellow to orange to red-orange as the reaction mixture was allowed to warm to room temperature. The reaction mixture was stirred for $1 \mathrm{~h}$ and the solvents were partially removed in vacuo. The concentrated solution was layered with $5 \mathrm{~mL}$ pentane. Bright red-orange solid crystallized out and was washed with $3 \mathrm{~mL}$ of cold (-30 $\left.{ }^{\circ} \mathrm{C}\right)$ pentane; yield $475 \mathrm{mg}(91 \%):{ }^{1} \mathrm{H}$ NMR $\left(\mathrm{C}_{6} \mathrm{D}_{6}\right) \delta 11.08\left(\mathrm{~s}, 1, \mathrm{CHCMe} 2 \mathrm{Ph}, J_{\mathrm{CH}}=122 \mathrm{~Hz}\right)$, 7.10-6.81 (overlapping peaks, 28, $\mathrm{ArH}, \mathrm{NPh} h_{2}$ ), 2.33 (s, 6, $\mathrm{CHCMe}_{2} \mathrm{Ph}$ ), 1.37 (s, 6, $\mathrm{Ar}^{\prime}$ $\left.\mathrm{Me}_{2}\right) ;{ }^{13} \mathrm{C} \mathrm{NMR}\left(\mathrm{C}_{6} \mathrm{D}_{6}\right) \delta 292.5,157.2,155.2,148.4,135.4,129.9,128.8,126.8,126.5,126.4$, 124.5, 123.6, 55.3, 30.5, 19.6. Anal. Calcd for $\mathrm{C}_{42} \mathrm{H}_{41} \mathrm{MoN}_{3}$ : C, 73.78; $\mathrm{H}, 6.04 ; \mathrm{N}, 6.15$. Found: C, 73.59; H, 6.12; N, 6.02 .

\section{Mo(NAr)(CH-t-Bu)[N(t-Bu)(3,5- $\left.\left.\mathrm{C}_{6} \mathrm{H}_{3} \mathrm{Me}_{2}\right)\right]_{2}$}

$\mathrm{LiN}(\mathrm{t}-\mathrm{Bu})\left(3,5-\mathrm{C}_{6} \mathrm{H}_{3} \mathrm{Me}_{2}\right)$ (ether) $(330 \mathrm{mg}, 1.28 \mathrm{mmol}$ ) was added to a suspension of $\mathrm{Mo}(\mathrm{NAr})$ $(\mathrm{CH}-\mathrm{t}-\mathrm{Bu})(\mathrm{OTf})_{2}(\mathrm{dme})(468 \mathrm{mg}, 0.64 \mathrm{mmol})$ in $30 \mathrm{~mL}$ ether at $-30{ }^{\circ} \mathrm{C}$. The red solution was stirred at ambient temperature for $1.5 \mathrm{~h}$. The volatiles were removed in vacuo and the residue 
was extracted into pentane. The pentane was removed in vacuo to give a red oil. Extensive trituration with cold pentane gave a waxy red solid. The waxy solid was dissolved in a minimum amount of pentane and the solution was stored at $-30{ }^{\circ} \mathrm{C}$ overnight to give $152 \mathrm{mg} \mathrm{(34 \% )} \mathrm{of}$ the product as orange-red crystals: ${ }^{1} \mathrm{H}$ NMR $\left(\mathrm{C}_{6} \mathrm{D}_{6}\right) \delta 10.71\left(\mathrm{~s}, 1, \mathrm{CHCMe}{ }_{3}, J_{\mathrm{CH}}=120 \mathrm{~Hz}\right)$, 7.17 (br s, 2, $\mathrm{ArH}$ ), 7.09 (br s, 5, $\mathrm{ArH}$ ), 6.68 (br s, 2, $\mathrm{ArH}$ ), 4.58 (sept, 2, $\mathrm{CHMe}$ ), 2.22 (s, 12, $\mathrm{C}_{6} \mathrm{H}_{3} \mathrm{Me}_{2}$ ), 1.38 (d, 12, $\mathrm{CHMe}$ ), 1.34 (s, 18, $\mathrm{NCMe}_{3}$ ), 0.98 (s, 9, $\left.\mathrm{CHCMe}_{3}\right) ;{ }^{13} \mathrm{C} \mathrm{NMR}$ $\left(\mathrm{C}_{6} \mathrm{D}_{6}\right) \delta 293.0,157.2,153.9,144.9,137.9,129.7,126.6,126.2,124.3,59.5,48.7,32.3,31.5$, 27.6, 24.6, 21.7. Anal. Calcd for $\mathrm{C}_{41} \mathrm{H}_{63} \mathrm{~N}_{3} \mathrm{Mo}$ : C, 70.97; H, 9.15; N, 6.06. Found: C, 71.06; H, 9.06; N, 5.97.

\section{$\mathrm{Mo}(\mathrm{NAr})(\mathrm{CH}-\mathrm{t}-\mathrm{Bu})\left[\mathrm{N}(\mathrm{i}-\mathrm{Pr})\left(3,5-\mathrm{C}_{6} \mathrm{H}_{3} \mathrm{Me}_{2}\right)\right]_{2}$}

An ether solution of $\mathrm{LiN}(\mathrm{i}-\mathrm{Pr})\left(3,5-\mathrm{C}_{6} \mathrm{H}_{3} \mathrm{Me}_{2}\right)(\mathrm{ether})(343 \mathrm{mg}, 1.41 \mathrm{mmol})$ was added to a suspension of $\mathrm{Mo}(\mathrm{NAr})(\mathrm{CH}-\mathrm{t}-\mathrm{Bu})(\mathrm{OTf})_{2}(\mathrm{dme})(6.00 \mathrm{~g}, 8.22 \mathrm{mmol})$ in $40 \mathrm{~mL}$ of ether at -30 ${ }^{\circ} \mathrm{C}$. The deep red reaction mixture at room temperature for $1 \mathrm{~h}$ and all solvents were removed under reduced pressure. The residue was extracted with pentane and the extract was filtered through Celite to yield a red liquid which was concentrated in vacuo to yield a red oil that contained $70 \% \mathrm{Mo}(\mathrm{NAr})(\mathrm{CH}-\mathrm{t}-\mathrm{Bu})\left[\mathrm{N}(\mathrm{i}-\mathrm{Pr})\left(3,5-\mathrm{C}_{6} \mathrm{H}_{3} \mathrm{Me}_{2}\right)\right]_{2}$ and $30 \% \mathrm{HN}(\mathrm{i}-\mathrm{Pr})(3,5-$

$\mathrm{C}_{6} \mathrm{H}_{3} \mathrm{Me}_{2}$ ) that could not be removed on a high vacuum line, or by heating the oil under reduced pressure: ${ }^{1} \mathrm{H}$ NMR $\left(\mathrm{C}_{6} \mathrm{D}_{6}\right) \delta 11.10\left(\mathrm{~s}, 1, \mathrm{CHCMe}_{3}, J_{\mathrm{CH}}=119 \mathrm{~Hz}\right), 7.07(\mathrm{br} \mathrm{s}, 3, \mathrm{ArH}), 6.85$ (br s, 4, $\mathrm{ArH}$ ), 6.56 (br s, 2, $\mathrm{ArH}$ ), 4.25 (sept, 2, $\mathrm{CHMe}_{2}$ ), 4.01 (sept, 2, $\mathrm{CHMe}$ ), 2.14 (s, 12, $\left.\mathrm{C}_{6} \mathrm{H}_{3} \mathrm{Me}_{2}\right), 1.26$ (d, 12, $\mathrm{CHMe}$ ), 1.23 (d, 12, CHMe $), 1.19$ (s, 9, CHCMe 3 ); ${ }^{13} \mathrm{C}$ NMR $\left(\mathrm{C}_{6} \mathrm{D}_{6}\right): \delta 285.2,154.9,145.0,138.5,126.4,125.0,123.7,123.2,58.6,48.4,32.2,28.2,25.4$, 25.0, 24.9, 21.9.

\section{Representative method for generating $\mathrm{Mo}\left(\mathrm{NR}^{\prime \prime}\right)\left(\mathrm{CHCMe}_{2} \mathrm{Ph}\right)\left(\right.$ diolate $\left.^{\star}\right)$ and using it as a catalyst for ring-closing}

The bisamido precursor $(10-20 \mathrm{mg})$ was added to a solution of the enantiomerically pure diol in $0.5 \mathrm{~mL}$ drops of benzene- $d_{6}$ in a J-Young tube. The reaction mixture was heated at $60{ }^{\circ} \mathrm{C}$ till the starting materials were consumed. The progress of the reaction was monitored by ${ }^{1} \mathrm{H}$ NMR spectroscopy versus an internal standard.

To the $\mathrm{Mo}\left(\mathrm{NR}^{\prime \prime}\right)\left(\mathrm{CHCMe}_{2} \mathrm{Ph}\right)($ diolate*) species generated as described above, 20 equivalents of the substrate was added. The conversion was followed by ${ }^{1} \mathrm{H}$ NMR spectroscopy and the enantiomeric excess was determined with a GC equipped with a Chiraldex column.

\section{Supplementary Material}

Refer to Web version on PubMed Central for supplementary material.

\section{Acknowledgements}

This research was funded by the NIH (GM-59426 to A.H.H. and R.R.S.) and the National Science Foundation (CHE-0138495 to R.R.S.). A.S. thanks Zachary Tonzetich for the gift of $\mathrm{LiNMe}_{2}$ and Adam Hock for the gift of LiN $(\mathrm{t}-\mathrm{Bu})\left(3,5-\mathrm{Me}_{2} \mathrm{C}_{6} \mathrm{H}_{3}\right)$ etherate.

\section{References}

1. Schrock RR, Hoveyda AH. Angew Chem Int Ed 2003;42:4592.

2. Copéret C, Chabanas M, Saint-Arroman RP, Basset JM. Angew Chem Int Ed 2003;42:156.

3. Teng X, Cefalo DR, Schrock RR, Hoveyda AH. J Am Chem Soc 2002;124:10779. [PubMed: 12207534]

4. Sinha A, Lopez LPH, Schrock RR, Hock AS, Müller P. Organometallics 2006;25:1412. 
5. Blanc F, Baudouin A, Copéret C, Thivolle-Cazat J, Basset JM, Lesage A, Emsley L, R SR. Angew Chem Int Ed 2006;45:1216.

6. Gade LH, Mountford P. Coord Chem Rev 2001;216-217:65.

7. Tsai YC, Diaconescu PL, Cummins CC. Organometallics 2000;19:5260.

8. Cherry JPF, Stephens FH, Johnson MJA, Diaconescu PL, Cummins CC. Inorg Chem 2001;40:6860. [PubMed: 11754262]

9. Stephens FH, Figueroa JS, Diaconescu PL, Cummins CC. J Am Chem Soc 2003;125:9264. [PubMed: 12889934]

10. (a) Zhang W, Kraft S, Moore JS. J Am Chem Soc 2004;126:329. [PubMed: 14709099] (b) Weissman H, Plunkett KN, Moore JS. Angew Chem Int Ed 2006;45:585. (c) Zhang W, Kraft S, Moore JS. Chem Commun 2003:832.

11. Schrock RR, DePue RT, Feldman J, Yap KB, Yang DC, Davis WM, Park LY, DiMare M, Schofield M, Anhaus J, Walborsky E, Evitt E, Krüger C, Betz P. Organometallics 1990;9:2262.

12. Jamieson JY, Schrock RR, Davis WM, Bonitatebus PJ, Zhu SS, Hoveyda AH. Organometallics 2000;19:92.

13. Ortiz CG, Abboud KA, Boncella JM. Organometallics 1999;18:4253.

14. (a) VanderLende DD, Abboud KA, Boncella JM. Organometallics 1994;13:3378. (b) Vaughan WM, Abboud KA, Boncella JM. J Am Chem Soc 1995;117:11015. (c) Wang SYS, VanderLende DD, Abboud KA, Boncella JM. Organometallics 1998;17:2628. (d) Vaughan WM, Abboud KA, Boncella JM. J Am Chem Soc 1995;117:11015.

15. Feldman J, Schrock RR. Prog Inorg Chem 1991;39:1.

16. Schrock RR. Chem Rev 2002;102:145. [PubMed: 11782131]

17. Schrock RR, Jamieson JY, Araujo JP, Bonitatebus PJ Jr, Sinha A, Lopez LPH. J Organomet Chem 2003;684:56.

18. Schrock RR, Murdzek JS, Bazan GC, Robbins J, DiMare M, O'Regan M. J Am Chem Soc 1990;112:3875.

19. Zhu SS, Cefalo DR, La DS, Jamieson JY, Davis WM, Hoveyda AH, Schrock RR. J Am Chem Soc 1999;121:8251.

20. Tsang WCP, Schrock RR, Hoveyda AH. Organometallics 2001;20:5658.

21. Totland KM, Boyd TJ, Lavoie GG, Davis WM, Schrock RR. Macromolecules 1996;29:6114.

22. Schrock RR, Jamieson JY, Dolman SJ, Miller SA, Bonitatebus PJ Jr, Hoveyda AH. Organometallics 2002;21:409.

23. Oskam JH, Fox HH, Yap KB, McConville DH, O'Dell R, Lichtenstein BJ, Schrock RR. J Organomet Chem 1993;459:185.

24. Tsai YC, Stephens FH, Meyer K, Mendiratta A, Gheorghiu MD, Cummins CC. Organometallics 2003;22:2902.

25. Micovic IV, Ivanovic MD, Piatak DM, Bojic VJ. Synthesis 1991:1043.

Organometallics. Author manuscript; available in PMC 2008 November 21. 

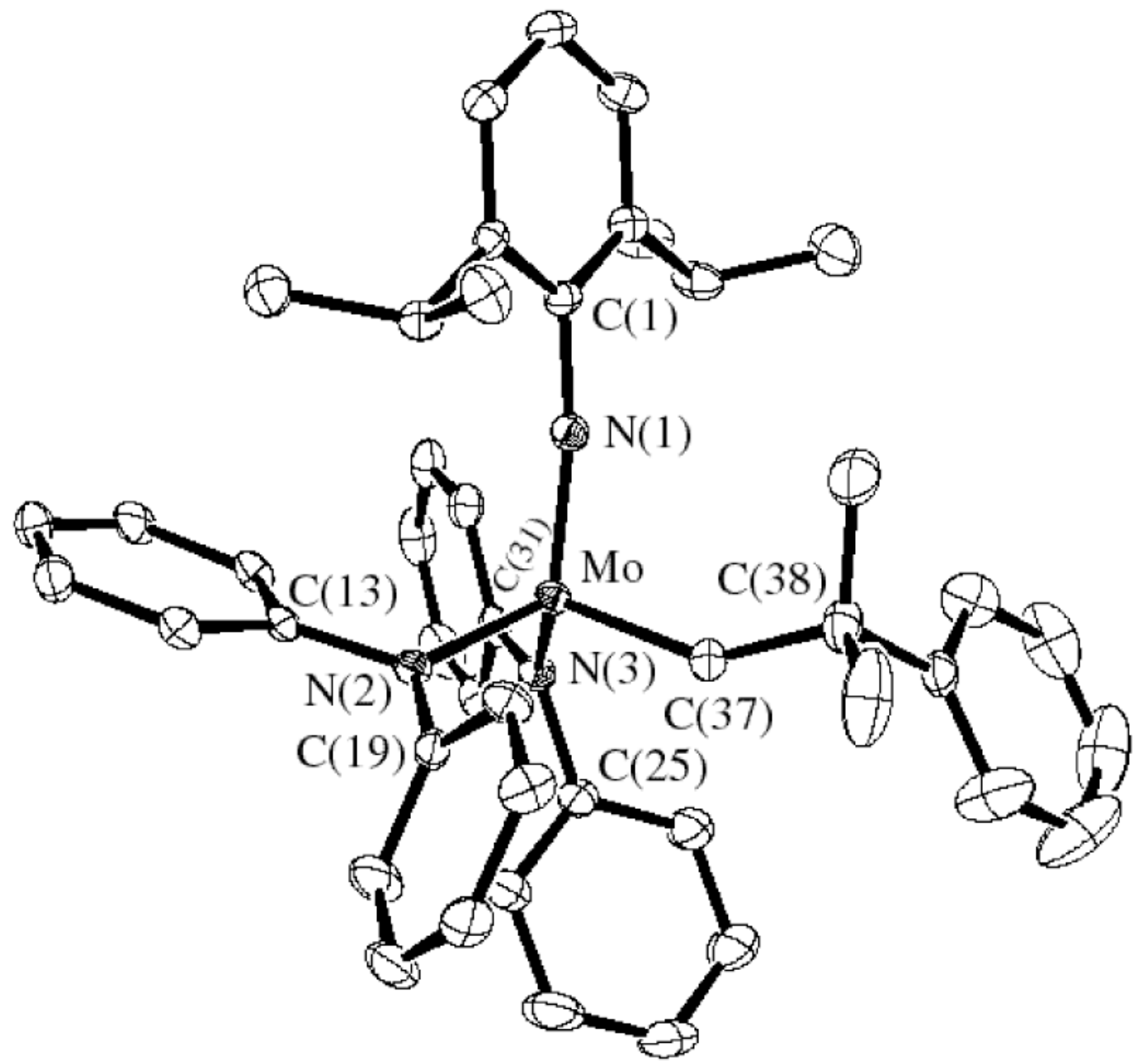

Figure 1.

Thermal ellipsoid drawing (50\%) of $\mathrm{Mo}(\mathrm{NAr})\left(\mathrm{CHCMe}_{2} \mathrm{Ph}\right)\left(\mathrm{NPh}_{2}\right)_{2}$. (Hydrogen atoms are removed for clarity.) 
Table 1

Crystal data and structure refinement for $\mathrm{Mo}(\mathrm{NAr})(\mathrm{CHCMe} 2 \mathrm{Ph})\left(\mathrm{NPh}_{2}\right)_{2}$.

\begin{tabular}{|c|c|c|}
\hline Empirical formula & $\mathrm{C}_{46} \mathrm{H}_{49} \mathrm{~N}_{3} \mathrm{Mo}$ & \\
\hline Formula weight & 739.82 & \\
\hline Temperature & $100(2) \mathrm{K}$ & \\
\hline Wavelength & $0.71073 \AA$ & \\
\hline Crystal system & Triclinic & \\
\hline Space group & $\mathrm{P} \overline{1}$ & \\
\hline Unit cell dimensions & $\begin{array}{l}\mathrm{a}=9.279(3) \AA \\
\mathrm{b}=20.158(7) \AA \\
\mathrm{c}=20.739(8) \AA\end{array}$ & $\begin{array}{l}\alpha=79.848(6)^{\circ} \\
\beta=89.997(6)^{\circ} \\
\gamma=83.507(6)^{\circ}\end{array}$ \\
\hline Volume & $3793(2) \AA^{3}$ & \\
\hline Z & 4 & \\
\hline Density (calculated) & $1.296 \mathrm{Mg} / \mathrm{m}^{3}$ & \\
\hline Absorption coefficient & $0.382 \mathrm{~mm}^{-1}$ & \\
\hline $\mathrm{F}(000)$ & 1552 & \\
\hline Crystal size & $0.20 \times 0.15 \times 0.05 \mathrm{~mm}^{3}$ & \\
\hline Theta range for data collection & 1.00 to $28.49^{\circ}$ & \\
\hline Index ranges & $-12 \leq \mathrm{h} \leq 12,-26 \leq \mathrm{k} \leq 27,0 \leq 1 \leq 27$ & \\
\hline Reflections collected & 23610 & \\
\hline Independent reflections & 23612 [non-merohedral twin] & \\
\hline Completeness to theta $=28.49^{\circ}$ & $97.2 \%$ & \\
\hline Absorption correction & Semi-empirical from equivalents & \\
\hline Max. and min. transmission & 0.9812 and 0.9276 & \\
\hline Refinement method & Full-matrix least-squares on $\mathrm{F}^{2}$ & \\
\hline Data / restraints / parameters & $23612 / 0 / 914$ & \\
\hline Goodness-of-fit on $\mathrm{F}^{2}$ & 1.020 & \\
\hline Final $R$ indices $[\mathrm{I}>2 \operatorname{sigma}(\mathrm{I})]$ & $\mathrm{R} 1=0.0486, \mathrm{wR} 2=0.1032$ & \\
\hline $\mathrm{R}$ indices (all data) & $\mathrm{R} 1=0.0726, \mathrm{wR} 2=0.1119$ & \\
\hline Largest diff. peak and hole & 0.946 and -0.517 e. $\AA^{-3}$ & \\
\hline
\end{tabular}


Table 2

Selected bond lengths $[\AA]$ and angles $\left[{ }^{\circ}\right]$ for $\mathrm{Mo}(\mathrm{NAr})\left(\mathrm{CHCMe} \mathrm{Ph}_{2}\right)\left(\mathrm{NPh}_{2}\right)_{2}$.

\begin{tabular}{llll}
\hline Mo-N(1) & $1.739(3)$ & Mo-C(37) & $1.877(3)$ \\
Mo-N(3) & $2.007(3)$ & Mo-N(2) & $2.009(3)$ \\
N(1)-C(1) & $1.406(4)$ & N(1)-Mo-C(37) & $103.98(13)$ \\
N(1)-Mo-N(2) & $114.03(11)$ & N(1)-Mo-N(3) & $116.34(11)$ \\
N(2)-Mo-N(3) & $110.32(10)$ & N(2)-Mo-C(37) & $104.07(12)$ \\
N(3)-Mo-C(37) & $106.86(12)$ & Mo-C(37)-C(38) & $146.2(3)$ \\
Mo-N(1)-C(1) & $169.0(2)$ & C(13)-N(2)-C(19) & $115.2(2)$ \\
C(13)-N(2)-Mo & $118.61(19)$ & C(19)-N(2)-Mo & $125.61(19)$ \\
C(31)-N(3)-C(25) & $117.6(3)$ & C(31)-N(3)-Mo & $132.3(2)$ \\
C(25)-N(3)-Mo & $110.1(2)$ & & \\
\hline
\end{tabular}


Table 3

NMR data for bisamido complexes in benzene- $d_{6}$ at $22{ }^{\circ} \mathrm{C}$.

\begin{tabular}{|c|c|c|c|}
\hline Compound & $\delta \mathbf{H}_{\alpha}$ & $\delta \mathrm{C}_{\alpha}$ & $J_{\mathrm{CH}}$ \\
\hline $\begin{array}{l}\mathrm{Mo}(\mathrm{NAr})(\mathrm{CH}-\mathrm{t}-\mathrm{Bu})\left[\mathrm{N}(\mathrm{t}-\mathrm{Bu})\left(3,5-\mathrm{C}_{6} \mathrm{H}_{3} \mathrm{Me}_{2}\right)\right]_{2} \\
\mathrm{Mo}(\mathrm{NAr})(\mathrm{CH}-\mathrm{t}-\mathrm{Bu})\left[\mathrm{N}(\mathrm{i}-\mathrm{Pr})\left(3,5-\mathrm{C}_{6} \mathrm{H}_{3} \mathrm{Me}_{2}\right)\right]_{2} \\
\mathrm{Mo}(\mathrm{NAr})(\mathrm{CH}-\mathrm{t}-\mathrm{Bu})\left(\mathrm{NPh}_{2}\right)_{2} \\
\mathrm{Mo}(\mathrm{NAr})\left(\mathrm{CHCMe}{ }_{2} \mathrm{Ph}\right)\left(\mathrm{NPh}_{2}\right)_{2} \\
\mathrm{Mo}\left(\mathrm{NAr}^{\prime}\right)\left(\mathrm{CHCMe}{ }_{2} \mathrm{Ph}\right)\left(\mathrm{NPh}_{2}\right)_{2}\end{array}$ & $\begin{array}{l}10.71 \\
11.10 \\
10.96 \\
11.18 \\
11.08\end{array}$ & $\begin{array}{l}293.0 \\
285.5 \\
294.8 \\
292.6 \\
292.5\end{array}$ & $\begin{array}{l}120 \\
119 \\
117 \\
119 \\
122\end{array}$ \\
\hline
\end{tabular}




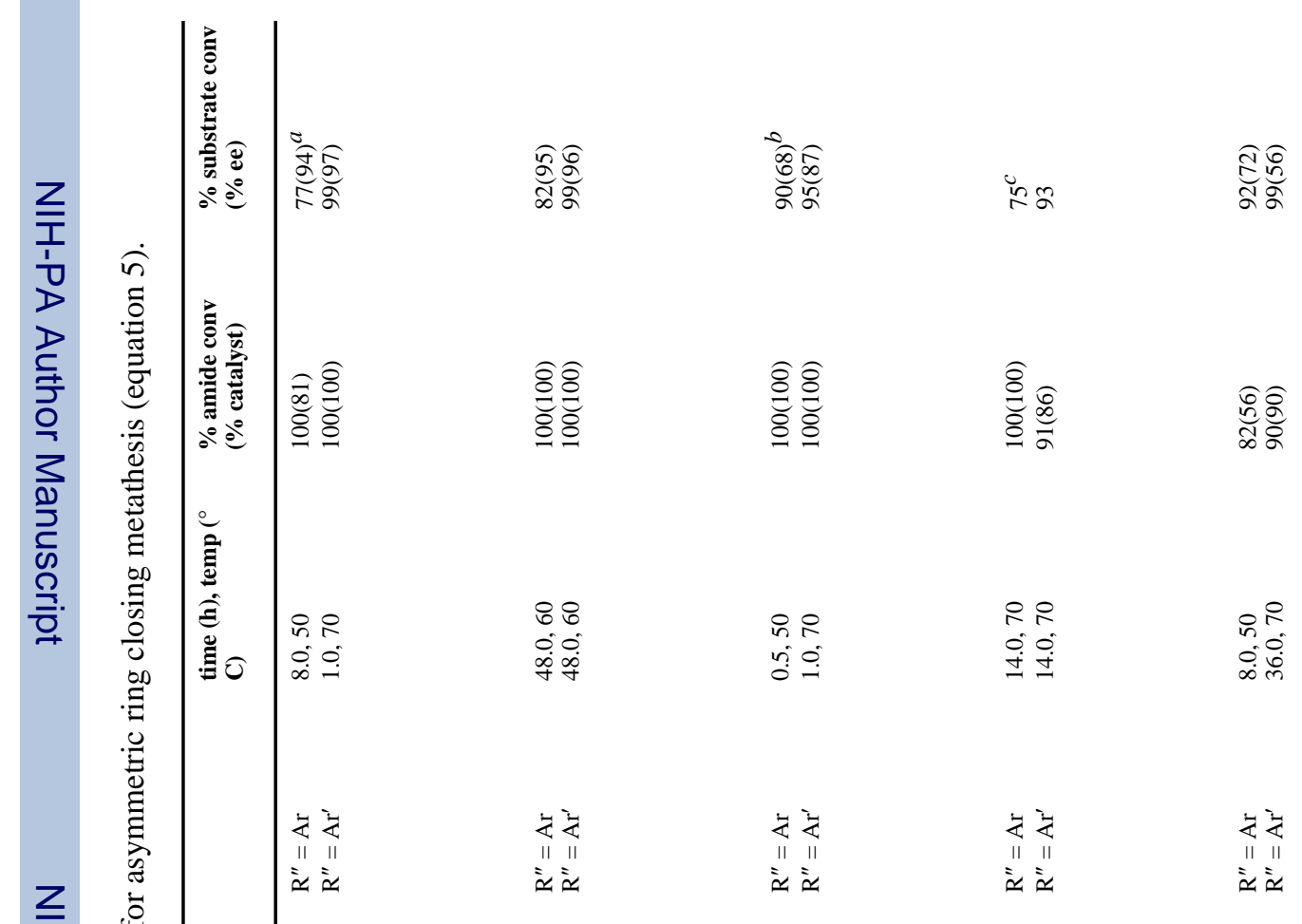
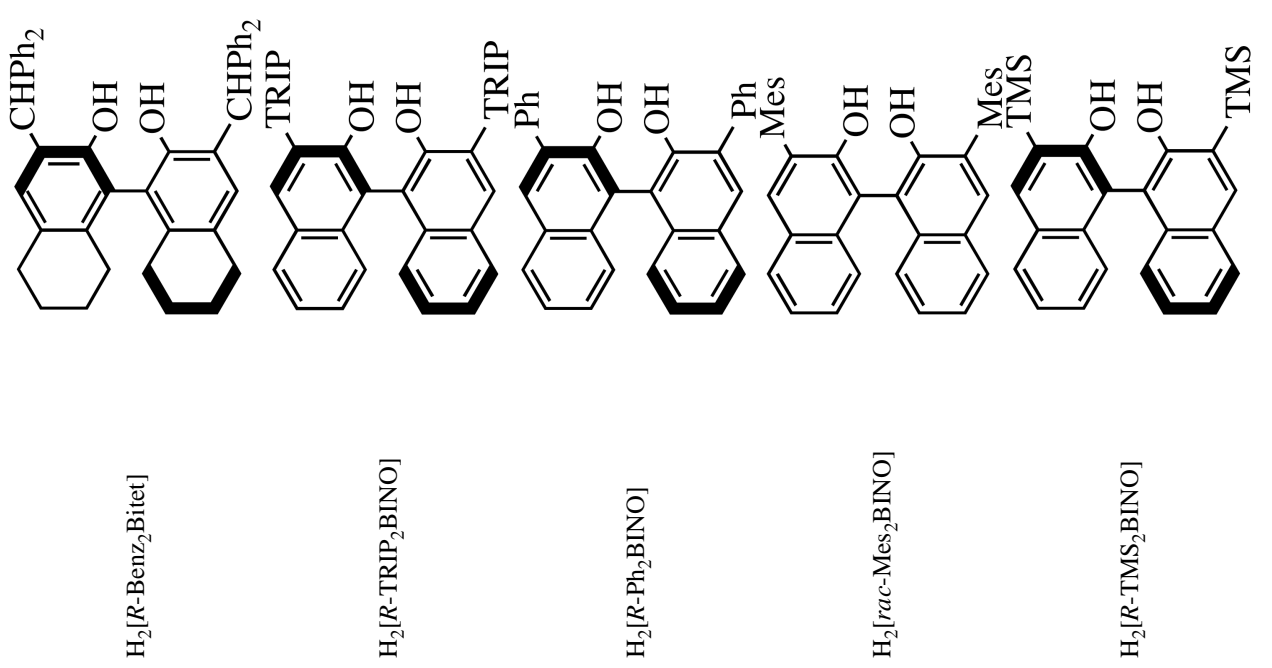

年

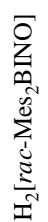

$\sum_{0}^{0}$

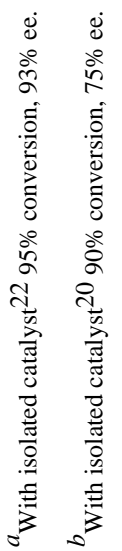


